\title{
Iskola az egészség alapköve? Miért és mit tegyen az iskola a tanulói egészségéért?
}

\author{
Is the school the cornerstone of health? Why and what should \\ schools do for pupil's health?
}

Szerző: $\quad$ Vitrai József $\square$
$\quad$ Emberi Erőforrások Minisztériuma

Beküldve: 2019.03. 31.

doi: $\quad$ 10.24365/ef.v60i2.445

\begin{abstract}
Összefoglaló: Rövid útmutató az iskoláknak, miért, hogyan tehetnek minél többet a gyermekek egészségéért, felhasználva a viselkedésváltoztatás elméleti kereteit.

Kulcsszavak: iskolai egészségfejlesztés; viselkedésváltozás
\end{abstract}

Summary: Short guidelines for schools on why and how they can do more for children's health using the theoretical framework of behavioral change.

Keywords: school health promotion; behavioral change

\section{MIÉRT LEGFONTOSABB ÉRTÉK AZ EGÉSZSÉGÜNK?}

Az egészség nem más, mint az elhatározásaink megvalósításának képessége. Azaz testi-lelki képesség az elhatározott cselekvéseink megvalósítására az adott körülmények között. Az egészségünktől függ, hogy meg tudjuk-e tenni azt, ami akarunk, és amire lehetőségünk lenne. Mindegy mennyire ismerjük a történelmet, mindegy milyen ügyesen tudunk megoldani matematikai feladatokat, testilelki egészségünk korlátozhatja tudásunk hasznosíthatóságát. Gyermek- és fiatalkorban az egészség befolyásolja, mennyi tudást szívunk magunkba, felnőttként milyen állást tudunk megszerezni, és ezáltal milyen életkörülményeket teremtünk, végső soron alapvetően befolyásolja, milyen pályát futunk be életünk során. Nem kétséges, mindannyiunk számára a saját egészségünk a boldogulásunk záloga, a legnagyobb értékeink egyike.

Szándékaink megvalósításának képességét, azaz egészségünket a szülőktől örökölt, illetve az életutunkon szerzett tulajdonságaink együtt biztosítják.
Az örökléstan legújabb eredményei rámutatnak arra, hogy a szülők életmódja, életkörülményei befolyásolják a születendő gyermek tulajdonságait (sőt, a gyermekek még tovább is örökíthetik saját gyerekeiknek). A szüleinktől kapott tulajdonságaink mellé - a születés pillanatától a halálig - a változó életkörülményeink között szerzett tapasztalataink befolyásolják életmódunkat és egészségünket. Megállapíthatjuk: pillanatnyi egészségünk sok-sok egyéni és környezeti tényező hatásának időbeli eredőjeként alakul.

Az előzőben leírtak az egyénről könnyedén kiterjeszthetők a közösségekre is: egy korosztálynak, egy város vagy falu lakosságának egészsége, produktivitása egy seregnyi tényező összegződő eredménye. Nyilvánvaló, ahhoz hogy egy közösség egészsége javuljon, az életkörülményeknek is javulniuk kell, változnia kell a környezettel és a hagyományokkal erősen meghatározott életmódnak is. Így érthető, hogy ezek a hagyományok, a már kialakult és megszokott körülmények, mint vendégmarasztaló sár, akadályozzák a változást, az egészség javítását. Könnyen belátható az is, hogy 
éppen az iskolában „átmeneti helyzetben” lévő gyermekek életmódja változtatható a legnagyobb eséllyel. Ők éppen leválnak a családról, de még nem léptek be a felnőttek világába, ezért náluk a legkisebb a hagyományok, szokások visszahúzó ereje.

\section{MIVEL KEZDJÜNK?}

„„... Raven Ultra például bőven elég a Mont Blanc normál útjára és csak 348 gramm." Leszámítva néhány hegymászót, az előző mondat a legtöbb embert „hidegen hagyja." Nem jegyzi meg, nem értelmezi az állítást. Nem, mert a magashegyi túrázás nem érdekes téma számára. Hasonló a helyzet a gyermekek többségével: hiába adnak nekik étkezési tanácsot, javasolnak több testmozgást, írják a dobozra, hogy a dohányzás káros az egészségre, ha számukra az egészség nem érdekes, nem fontos. Ezért az első lépés elérni, hogy megértsék, boldogulásuk záloga az, hogy egészségesek maradjanak. Az egészségnek belső értékké kell válnia ahhoz, hogy kiemelt szempont legyen döntéseiknél, hogy a lehető legtöbbször az egészségesebbet válasszák. Ha fontossá válik az egészség, akkor érdekessé válik az, amit azzal kapcsolatban nekik elmondanak, megmutatnak.

\section{COMB}

Ez nem egy testrész, hanem egy angol betűszó, a Capability, Opportunity, Motivation, Behavior szavakat rövidíti, amiket magyarra így fordítunk: képesség, szándék, környezet, viselkedés. A modern pszichológia szerint a viselkedést a testi-lelki képességek, a szándék és a társas-fizikai környezet együttesen határozza meg. ${ }^{1,2}$ Tehát ahhoz, hogy a gyermekek viselkedése megváltozzon, életmódja egészségesebb legyen, a képesség, szándék, környezet területén kell változást elérni. Nem elég ugyanis az egészséggel kapcsolatos ismereteiket bővíteni, készségeiket fejleszteni, hanem motiválni is kell őket, hogy akarjanak is egészségesen élni. És ha már tudnának és akarnának is egészségesen élni, akkor arra még lehetőséget is kell kapniuk. Támogatást, bíztatást szüleiktől, barátaiktól, az őket tanító pedagógusoktól, és helyet, időt, lehetőséget egészségesen étkezni, sokat mozogni és szabad- idejüket tartalmasan és egyúttal szórakoztatóan, közösségben eltölteni. A COMB elemei egymásra "oda-vissza” is hatnak: a gyermek egészségről szerzett ismeretei (képesség) miatt az egészség fontossá válik számára, ezért úgy dönt (szándék), arról újabb ismereteket fog szerezni, és olvasnivalót keres (viselkedés) például a testmozgás előtti helyes bemelegítésről.

\section{MIRE JÓ A COMB AZ ISKOLÁNAK?}

\section{Képesség}

Kezdjük az ismeretbővítéssel! Milyen ismeretekre van szüksége egy gyermeknek az egészséges életmódhoz? Először is azt kell megértenie, hogy egészség nélkül semmi nincs. Hogy például egy baleset meggátolhatja, hogy focizzon, vagy az elhízástól kialakuló cukorbetegség, hogy kedve szerint csokit, fagyit egyen. Tudnia kell továbbá, hogy az egészség több a fizikai jóllétnél, hogy azon túl szüksége van az önmegvalósítását támogató családra, barátokra, iskolai közösségre. Meg kell ismernie, mik veszélyeztetik egészségét, mik lehetnek például a dohányzás, az alkoholfogyasztás következményei. El kell érni, hogy tudja magáról, hogy korának megfelelően, gyakran a következmények mérlegelése nélkül dönt, kockáztat, veszélyezteti egészségét. Az ilyen ismeretek elsajátítását az átélt élmények segítik, ezért a következményekkel szembesítés, mint egy volt alkoholistával vagy drogossal való beszélgetés, vagy az iskolaudvaron elhelyezett, balesetre emlékeztető autóroncs igen hatásos lehet.

Természetesen a tudáson túl egy gyermeknek sokféle készségre is szüksége van a kockázatok elkerüléséhez, az egészséges élethez. Gyakorlatot kell szereznie például az alkohollal, droggal kínálás vagy az erőszakos közeledés elhárítására. Jó, ha elsajátíthat alapszinten szabadidős tevékenységeket, mint például sportot, ételkészítést, kipróbálhatja magát különféle művészeti ágakban, mint karéneklésben vagy videokészítésben. Nagyon fontos, hogy a közösségi életben való sikeres részvételhez szükséges készségekre szert tegyen, mint a kapcsolatok kiépítése, ápolása, a hatásos kommunikáció, vagy támogatás nyújtása, kérése és elfogadása. 
Szándék

Következő terület a helyes egészségmagatartásra motiválás. Az egészség fejlesztésére irányuló cselekvés szándékát kiépíteni talán leghatékonyabban a mintaadással lehet. Az iskolai dolgozók egészségmagatartása döntő hatással lehet a tanulók egészséggel kapcsolatos viselkedésére. Ha a gyermekek azt látják, hogy az iskolában a felnőtteknek fontos az egészség, és azért sok mindent megtesznek (pl. nem dohányoznak, kerékpárral járnak iskolába, aktívan részt vesznek az iskolai sportrendezvényeken, egészségesen étkeznek), akkor az egészséges életmódot fogják természetesnek, követendő normának tartani.

Környezet

A képessé tett és motivált gyermekek számára az iskola egyedülálló, egészséges életmódot támogató környezetet nyújthat. Egyrészt olyan kultúrát, amelyben az egészség kiemelt értéket képvisel, és ennek megfelelően az iskolai életben kulcsfontosságú szempontként jelenik meg. A gyermekeknek fel kell ismerniük, hogy az egészség az iskolában döntő szempont a közösségi értékek, a hagyományok, az ünnepek kialakításában, a rendezvények szervezésében, a tanulók és az osztályok teljesítményének értékelésében. Tapasztalniuk kell, hogy az iskolai környezet kialakításakor a testi-lelki egészségnek kiemelkedő jelentőséget tulajdonítanak. Például az iskola vezetősége gondoskodik a tisztaságról, a mosdók személyi higiénének megfelelő felszereltségéről, az egészséges étkezésnek megfelelő helyről és elegendő időről, a közösségi aktivitásokhoz, mint a színjátszás vagy különféle szakkörökhöz, sportoláshoz nélkülözhetetlen terekről, eszközökről.

Hogy a tanulók ki is használják az iskola által nyújtott lehetőségeket, az iskolai közösségnek mozgósítania, ösztönöznie kell erre a tanulókat. A mozgósító, a már elért eredményre alapozva bíztató verbális és vizuális, az egyént célzó kommunikáció lehet a motiválás egyik eszköze. Gondolhatunk itt például a Netfit eredmények további erőfeszítésre ösztökélő visszacsatolására, vagy a sport vagy más iskolai rendezvényeket, vetélkedőket népszerűsítő plakátokra, de a személyes higiénét reklámozó feliratokra is a mosdókban és az étteremben. Másik kiváló motiváló eszköz olyan események, rendezvények szervezése, melyek a közösséghez való tartozást, a közösségéért cselekvést állítják fókuszukba. Ilyenek lehetnek a tanulócsoportok, az osztályok vagy az iskolák egymás közti versengése, akár testmozgást igénylő helytörténeti vetélkedők vagy akár sportversenyek keretében. A közösségért küzdés az egészséges életmódhoz nemcsak motiváló erőt jelent, és követendő normát közvetít egy-egy gyermek számára, hanem egyúttal a mentális egészséghez nélkülözhetetlen társas támogatás kifejeződését is.

\section{HOGYAN TOVÁBB?}

Egyrészt a pedagógusok és az iskola nagyobb elismertségére, és erre építve az iskola jelentősebb szerepvállalására a helyi társadalom életében. Másrészt a helyi társadalom jelentősebb felelősségvállalására az iskolások egészségének támogatásában.

A helyi táradalom előnyére válik, ha a magasan képzett és tapasztalt pedagógusok jobban bekapcsolódnak a közösség életébe, és korunkban ismét véleményformálókká, hangadókká válnak. A tanítók, a tanárok társadalmi státuszának emelkedése elengedhetetlen kommunikációjuk hitelességének növekedéséhez. Ha egy diák felnéz tanárára, követendő példának látja, akkor a pedagógus eredményesebben bővítheti a tanulók egészséggel kapcsolatos tudását, motiválhatja őket egészségesebb életmódra.

A pedagógusoknak, a helyi közösségben való komolyabb elismertsége ahhoz is szükséges, hogy az iskola erősebben befolyásolhassa a szülőket és a helyi társadalom egyéb szereplőit a gyermekek egészségének védelme, fejlesztése érdekében. Elérheti például, hogy az önkormányzat fejlessze a kerékpárral iskolába járás lehetőségét, biztonságát, hogy az iskola környékén korlátozzák a gyorsételek és a cukros üdítők árusítását. Megnövekedett befolyása révén az iskola a tanulói számára lehetőséget kaphat sportlétesítmények kedvezményes használatára vagy anyagi támogatást egészségesebb iskolai környezet kialakítására, közösségi aktivitást szolgáló eszközök, felszerelés vásárlására. 
A felnőttek világa, az otthoni és iskolai körülmények alapvetően meghatározzák a gyerekek egészségét. Könnyen belátható, ahhoz hogy a gyermekeink egészségesebben éljenek, a pedagógusoknak nem elég a COMB-ot figyelembe venniük, az iskolának ki kell terjesztenie tevékenységét, befolyását a falain kívülre.

\section{KÖSZÖNETNYILVÁNITTÁS}

A közlemény létrejöttét a 21 Nő az Egészségügyért Alapítvány támogatta.

\section{HIVATKOZÁSOK}

\footnotetext{
${ }^{1}$ Michie S, van Stralen MM, West R. The behaviour change wheel: A new method for characterising and designing behaviour change interventions. Implementation Science 2011, 6:42.

${ }^{2}$ Vitrai J, Kimmel Zs. Mennyire változtatható jogszabályokkal az egészségmagatartás? Mitől függ és hogyan változtatható az egészségmagatartás? I. rész. Egészségtudomány, 2015.3:57-70.
} 